\title{
PENGARUH KEPUASAN, KEPERCAYAAN DAN HARGA TERHADAP LOYALITAS WISATAWAN PENGGUNA LAYANAN BOOKING.COM
}

\author{
Ni Luh Lisa Wulandari \\ I Made Kusuma Negara \\ Luh Gede Leli Kusuma Dewi \\ Email : lisa.wulan@gmail.com \\ PS. S1 Industri Perjalanan Wisata \\ Fakultas Pariwisata UNUD
}

\begin{abstract}
Online Travel Agent is popular sites as travel planner for tourist. Online Travel Agent provides ease on choosing accommodation or other tour facility for tourist. Booking.com is the biggest online travel agent at this time which giving service on reserving hotel room. Booking.com becomes popular among the tourist and very interested especially for reserved hotel room due to Booking.com provide additional facility which given for customer who loyal using service this online travel agent. Therefore, the purpose of this study is to know The Effect of Satisfaction, Trust and Price on Tourist Loyalty who uses Service of Booking.com.

Sample on this research is 100 respondents with using quota sampling technique directed to tourist who ever using service of Booking.com more than 1 time and classified as Secret Deal and Genius Booker Customer. Collecting Data technique are observation non participation, questionnaire with likert scale, literature study and online survey.

By hypothesis test with $t$ test and $F$ test, the result are (1) Satisfaction has influence positive and significant on Loyalty of Tourist. (2) Trust has influence positive and significant on Loyalty of Tourist (3) Price has influence positive and significant on Loyalty of Tourist.(4) Satisfaction, Trust and Price has influence positive and significant on Loyalty of Tourist as simultaneous. Through coefficient determination test Satisfaction, Trust and Price variable able to explain Loyalty 70,60\%. Linier Regression Analyze state that independent variable has positive coefficient value 2,593, 2,303 and 4,988 with result Price as independent variable which very dominant influence Loyalty of Tourist for using service online travel agent Booking.com.
\end{abstract}

Keywords: Online Travel Agent, Satisfaction, Trust, Price, Loyalty.

\section{PENDAHULUAN}

Perkembangan teknologi dan informasi saat ini memberikan pengaruh besar dalam perkembangan pariwisata. Teknologi menjadi kebutuhan bagi wisatawan dalam merencanakan perjalanan wisata. Salah satu hasil perkembangan teknologi adalah online travel agent. Online Travel Agent saat ini begitu populer dikalangan wisatawan. Wisatawan lebih memilih menggunakan online travel agent karena harga yang lebih murah, adanya rekomendasi terhadap suatu property, lebih banyak pilihan property yang diberikan dengan kategori pencarian yang tepat sehingga jumlah pilihan akan property yang akan dikunjungi tidak dibatasi, serta adanya reward yang diberikan oleh online travel agentuntuk customer yang loyal menggunakan online travel agent tersebut ( Research: Digital is Key, 2014). Booking.Com merupakan salah satu online travel agent yang bergerak dalam jasa pemesanan kamar hotel. Setiap perusahaan tentu mengharapkan loyalitas dari pelanggannya, hal yang sama diharapkan oleh Booking.com untuk memperoleh loyalitas wisatawan maka isu 
terpenting dalam bisnis online travel agent adalah tentang kepuasan, kepercayaan dan harga yang akan mempengaruhi loyalitas wisatawan dalam menggunakan pelayanan Booking.com.

Booking.com merupakan salah satu online travel agent yang memberikan perhatian pada loyalitas wisatawan dengan memberikan fasilitas tambahan bagi wisatawan yang sering menggunakan layanan Booking.com.

Kepuasan merupakan perasaan yang dirasakan oleh wisatawan secara psikologis tentang harapannya dengan kenyataan yang diterima terhadap produk jasa layanan dari Online Travel Agent Booking.com (Lombards, 2009). Kepuasan diukur dengan dimensi variabel menurut Wilkie (1994) dan Kotler yaitu harapan, kinerja, performance, perbandingan, dan menciptakan keputusan pembelian. Kepuasan adalah sebuah kunci dalam mebentuk sikap pembelian berulang dari wisatawan pada masa yang akan datang. Dalam beberapa penelitian seperti yang dilakukan oleh Ernawati (2012) menyatakan bahwa kepuasan, kepercayaan dan harga dengan sangat kuat mempengaruhi loyalitas wisatawan.

$\begin{array}{ccr}\text { Kepercayaan } & \text { adalah } & \text { kesediaan } \\ \text { (willingness) } & \text { seseorang } & \text { untuk }\end{array}$
menggantungkan dirinya pada orang lain dengan besaran resiko tertentu, (Lau dan Lee, 1999) dalam (Putro, 2008). Kim et all (2008) dan Doney \& Canon (1997) dalam Herington (2003) menyatakan bahwa kepercayaan dapat diukur melalui dimensi variabel kemampuan (ability), kebaikan hati (benevolence), integritas (integrity), kepedulian dan kredibilitas. Penelitian yang dilakukan oleh Sarwar (2012) menyatakan bahwa kepercayaan berpengaruh positif terhadap loyalitas wisatawan. Kepercayaan merupakan karakter terpenting dalam mewujudkan hubungan jangka panjang di masa depan.

Harga adalah nilai dari suatu produk atau jasa yang harus dibayarkan oleh wisatawan ketika ingin menikmati produk atau jasa tersebut. Harga adalah nilai yang dipajang pada website Booking.com untuk menjual kamar hotel. McCharty (2008) dan Stanton (2006) dalam Weenas (2003) menyebutkan harga dapat diukur dengan indikator potongan harga, fluktuasi harga, variasi harga, tingkat harga dan kesesuaian harga dengan kualitas produk atau jasa. Virvilaite (2009) dalam penelitiannya menyatakan bahwa pelayanan akan harga (service price), adalah salah satu faktor yang mempengaruhi loyalitas wisatawan. Kewajaran dan keadilan dalam penentuan harga sangat mempengaruhi loyalitas wisatawan secara langsung.

Loyalitas adalah wujud perilaku pengambilan keputusan untuk melakukan pembelian secara terus menerus terhadap suatu jasa perusahaan, (Griffin, 2007). Loyalitas diukur dengan indikator pemesanan secara berulang (repeat purchase), referalls, merekomendasikan kepada orang lain (recommendation), membicarakan hal-hal yang positif, ketahanan dari tarikan pesaing (retention). Harga, Kepuasan, Kepercayaan adalah 3 variabel yang saling terkait dalam mempengaruhi loyalitas wisatawan.

Pembelian yang berulang tentu didasari oleh kepercayaan yang tinggi dari wisatawan. Kepercayaan tidak hanya dibatasi dengan produk tetapi bagaimana perusahaan menjaga kepercayaan tersebut. Dengan adanya kepuasan dan kepercayaan akan mulai terjalinnya hubungan jangka panjang antara wisatawan dan perusahaan. Orientasi jangka panjang terhadap penentuan harga, peningkatan akan kepuasan dan kepercayaan wisatawan adalah faktor penting yang diperhatikan oleh wisatawan bila perusahaan ingin wisatawan yang menggunakan produknya akan selalu loyal pada perusahaan. Dapat dijelaskan tujuan dari penelitian yang telah dilakukan adalah untuk mengetahui Pengaruh Kepuasan, Kepercayaan dan Harga terhadap Loyalitas Wisatawan pengguna Layanan Booking.com baik secara parsial maupun secara simultan.

\section{METODE PENELITIAN}

Terdapat 4 variabel yaitu Kepuasan $\left(\mathrm{x}_{1}\right)$, Kepercayaan $\left(\mathrm{x}_{2}\right)$ dan Harga $\left(\mathrm{x}_{3}\right)$ sebagai variabel bebas dan Loyalitas (y) sebagai variable terikat. Kriteria responden adalah tertuju pada wisatawan yang telah menggunakan layanan Booking.com lebih dari 1 kali. Dalam penentuan sampel digunakan teknik quota sampling dengan jumlah sampel sebanyak 100 responden. Dalam pengumpulan data digunakan teknik observasi non partisipasi, kuisioner, studi kepustakaan dan survey online.

Teknik analisis data yang digunakan adalah kualitatif dan kuantitatif. Analisis data kualitatif dengan menggunakan skala likert 
sedangkan analisis data kuantitatif menggunakan uji instrument (uji validitas dan uji reliabilitas), uji asumsi klasik (uji normalitas, uji multikolinieritas dan uji heteroskedastisitas. Guna melihat pengaruh variable $\mathrm{x}$ terhadap variable y maka digunakan Analisis Regresi Linier Berganda, Analisis Korelasi dan Koefisien Determinasi. Pengujian Hipotesis menggunakan uji $\mathrm{t}$ (parsial) dan uji $\mathrm{F}$ (simultan).

\section{HASIL DAN PEMBAHASAN Uji Instrumen Data}

Instrumen data diuji dengan menggunakan uji validitas dan reliabilitas untuk mengetahui pernyataan dalam kuisioner telah sahih dan handal serta dapat dipercaya dalam pengambilan data penelitian.

Hasil Uji Validitas dengan pengujian statistik yang telah dilakukan terhadap seluruh item kuisioner menunjukkan bahwa seluruh item pertanyaan dalam kuisioner semuanya valid. Seluruh indikator dalam kuisioner memiliki nilai $r_{\text {hitung }}$ lebih besar dari nilai $r_{\text {tabel }}$ $(0,196)$ dimana berdasarkan Product Moment Pearson, item kuisioner telah valid

Pada uji realibilitas yang telah dilakukan dengan rumus alpha cronbanch, diketahui bahwa seluruh indikator variabel memiliki nilai koefisien alpha yang lebih besar dari 0,6, dimana indikator - indikator dalam kuisioner dinyatakan reliable untuk pengambilan data penelitian.

\section{Uji Asumsi Klasik}

Uji Asumsi Klasik dilakukan untuk mengetahui model regresi yang dihasilkan tidak mengandung gejala - gejala asumsi klasik. Uji asumsi klasik yang digunakan adalah Uji Normalitas, Uji Multikolinieritas dan Uji Heteroskedastisitas.

Berdasarkan hasil tes uji normalitas dengan Kolmogorov Smirnov Test diketahui bahwa nilai signifikansi atau Asymp Sig (2tailed) pada uji Kolmogorov Smirnov sebesar 0,169 . Nilai signifikansi alpha 0,169 adalah lebih besar dari 0,05 dengan demikian variabel - variabel dalam penelitian ini telah berdistribusi normal.

Pada uji multikolinieritas diketahui bahwa nilai tolerance value $\geq 0,10$ dan nilai Variance Inflation Factor di bawah 10, maka dapat dijelaskan bahwa tidak adanya korelasi di antara variabel bebas dengan kata lain model regresi yang dihasilkan tidak mengandung gejala multikolinieritas.

Sedangkan hasil Uji Heteroskedastisitas dengan menggunakan Glejser Test menunjukkan nilai signifikansi antara variabel independen dengan absolut residual $\geq 0,05$ berdasarkan kriteria pengujian Glejser Test maka model regresi yang dihasilkan tidak terjadi masalah heteroskedastisitas dengan kata lain model regresi layak digunakan untuk memprediksi loyalitas wisatawan dilihat dari pengaruh variabel kepuasan, kepercayaan dan harga.

\section{Analisis Regresi Linier Berganda dan Korelasi}

Analisis regresi linier berganda digunakan untuk mengukur pengaruh kepuasan (variabel bebas), kepercayaan (variabel bebas), dan harga (variabel bebas), terhadap loyalitas (variabel terikat) secara bersama - sama.

Berdasarkan hasil analisis korelasi untuk melihat hubungan variabel bebas kepuasan $\left(\mathrm{x}_{1}\right)$, kepercayaan $\left(\mathrm{x}_{2}\right)$ dan harga $\left(\mathrm{x}_{3}\right)$ terhadap loyalitas (y) diperoleh hasil nilai $\mathrm{R}$ sebesar 0,846. Diketahui bahwa korelasi antara variabel bebas dan terikat berada pada kategori kuat dengan arah yang positif yang berarti apabila kepuasan dan kepercayaan meningkat serta nilai keuntungan harga bagi wisatawan juga meningkat maka akan meningkatkan loyalitas wisatawan, tetapi sebaliknya apabila ketiga variabel tersebut mengalami penurunan diikuti pula dengan loyalitas wisatawan yang juga akan menurun.

\section{Koefisien Determinasi}

Pada Koefisien Determinasi diketahui nilai Adjusted R Square sebesar 70,60 \%. Hasil tersebut menunjukkan bahwa persentase pengaruh kepuasan, kepercayaan dan harga terhadap loyalitas wisatawan pengguna layanan Booking.com sebesar 70,60\%. Sedangkan sisanya sebesar 29,40 \% dijelaskan oleh variabel lain yang terkait dalam meningkatkan loyalitas wisatawan.

\section{Uji Hipotesis}

Uji $t$ digunakan untuk mengetahui pengaruh variabel bebas terhadap variabel terikat secara parsial. Hasil uji t menerangkan bahwa nilai $t_{\text {hitungvariabel kepuasan, }}$ kepercayaan dan harga $(2,593,2,303$ dan $4,988)$ lebih besar dari nilai $t_{\text {tabel }}(1,661)$ dan 
nilai signifikansi dari variabel kepuasan, kepercayaan dan harga $(0,011,0,023,0,000)$ yang kurang dari 0,05 maka diketahui bahwa hipotesis diterima.

Uji $F$ bertujuan untuk mengetahui pengaruh Kepuasan, Kepercayaan dan Harga secara bersama - sama (simultan) terhadap variabel loyalitas. Hasil uji $F$ atau ANOVA menyatakan bahwa nilai $\mathrm{f}_{\text {hitung }}$ lebih besar dari nilai $\mathrm{f}_{\text {tabel }}$ yaitu sebesar 80,284 $>2,70$ dengan nilai signifikansi yang lebih kecil dari 0,05 yaitu sebesar 0,000 .

Dari hasil Analisis Regresi Berganda menghasilkan model regresi yaitu $Y=$ $0,168+0,236 X 1+0,252 X 2+0,480 X 3+$ $e$ dimana nilai koefisien regresi adalah positif yang mengindikasikan bahwa semakin meningkat variabel $\mathrm{x}$ maka akan mempengaruhi pula peningkatan pada variabel y. Berdasarkan hasil uji hipotesis uji $t$ dan uji F dapat dibahas sebagai berikut:

1. Pengaruh Kepuasan Terhadap Loyalitas Wisatawan Pengguna Layanan Booking.com. Diperoleh hasil bahwa kepuasan $\left(\mathrm{x}_{1}\right)$ berpengaruh positif dan signifikan terhadap loyalitas (y) wisatawan pengguna layanan Booking.com, dengan nilai signifikansi variabel kepuasan adalah 0,011 dimana nilai tersebut kurang dari $\alpha$ $=0,05$ dan nilai $t_{\text {hitung }}$ lebih besar dari nilai $t_{\text {tabel }}$ yaitu sebesar 2,593 > 1,661. Hasil tersebut dengan arah yang positif yang berarti semakin tinggi kepuasan wisatawan maka akan semakin meningkatkan loyalitas wisatawan dalam menggunakan layanan Booking.com. Kepuasan wisatawan yang menggunakan layanan Booking.com membuat wisatawan menjadi wisatawan yang loyal. Hubungan yang dibentuk oleh Booking.com kepada wisatawan dan pihak properti terintegrasi dengan baik dalam mewujudkan kepuasan wisatawan karena kepuasan adalah tentang bagaimana hubungan yang terjalin antara wisatawan dengan produk yang mereka beli dalam hal ini akomodasi yang mereka sewa pada suatu properti dan media yang mereka gunakan untuk memesan akomodasi tersebut atau hubungan diantara pelayanan yang diterima oleh wisatawan dengan penyedia pelayanan jasa tersebut.

2. Pengaruh Kepercayaan Terhadap Loyalitas Wisatawan Pengguna Layanan
Booking.com. Pengaruh Kepercayaan Terhadap Loyalitas Wisatawan, diketahui dari hasil uji t menunjukkan bahwa nilai signifikansi variabel kepercayaan adalah sebesar 0,023 dimana nilai tersebut kurang dari nilai $\alpha 0,05$ serta nilai $t_{\text {hitung }}$ lebih besar dari nilai $t_{\text {tabel }}$ yaitu 2,303 $>1,661$ dan hipotesis diterima dengan arah yang positif, semakin meningkat kepercayaan wisatawan maka akan semakin meningkat pula loyalitas wisatawan untuk menggunakan kembali layanan Booking.com. Kepercayaan dapat dilihat dari cara perusahaan dalam memelihara hubungan yang telah dijalin dengan wisatawan. Kepercayaan dapat terjadi karena telah adanya kepuasan yang dirasakan sebelumnya melalui pengalaman wisatawan. Kepercayaan menjadi proses yang berkelanjutan, semakin baik Booking.com menjaga kepercayaan wisatawan maka akan semakin kepercayaan tersebut kuat dan menjadikan mereka sebagai wisatawan yang loyal.

3. Pengaruh Harga Terhadap Loyalitas Wisatawan Pengguna Layanan Booking.com. Harga merupakan salah satu variabel yang mempengaruhi loyalitas wisatawan dalam menggunakan layanan Booking.com dilihat dari nilai signifikansi pada uji $t$ terhadap variabel harga sebesar 0,000 yang merupakan kurang dari 0,05 dan nilai $t_{\text {hitung }}$ dari variabel harga menunjukkan pula nilai yang lebih besar dari $t_{\text {tabel }}$ yaitu sebesar $4,988>1,661$. Variabel harga layak sebagai salah satu penentu loyalitas wisatawan. Dalam meningkatkan loyalitas wisatawan maka strategi penetapan harga melalui potongan harga yang relevan dan lebih murah dibandingkan pesaing lainnya perlu untuk dilakukan. Hal ini dikarenakan harga bersifat sangat sensitive, harga yang murah akan mempengaruhi wisatawan untuk terus melakukan keputusan pembelian, tetapi apabila harga tersebut naik sedikit saja, maka wisatawan akan mencoba untuk menemukan alternatif pelayanan sejenis dengan harga yang lebih murah.

4. Pengaruh Kepuasan, Kepercayaan dan Harga Terhadap Loyalitas Wisatawan Pengguna Layanan Booking.com Kepuasan, Kepercayaan dan Harga dapat mempengaruhi Loyalitas secara serempak. 
Hal ini dibuktikan pada uji $\mathrm{F}$ diperoleh hasil nilai signifikansi sebesar 0,000 dan kurang dari 0,05 dan nilai $F_{\text {hitung lebih }}$ besar dari $\mathrm{F}_{\text {tabel }}$ yaitu 80,2 $>2,70$. Hal ini berarti bahwa Kepuasan, Kepercayaan dan Harga secara serempak berpengaruh terhadap loyalitas wisatawan dalam menggunakan layanan Booking.com.

Dapat disimpulkan bahwa dengan adanya kepuasan dan kepercayaan akan harga maka wisatawan akan menjadi wisatawan yang loyal dalam menggunakan layanan Booking.com. Harga menjadi variabel yang paling mendominasi dalam mempengaruhi loyalitas wisatawan. Dalam tahap loyalitas yang tinggi wisatawan harga merupakan hal terpenting, dengan harga yang kompetitif maka wisatawan akan selalu menggunakan jasa tersebut dan tidak akan meninggalkan jasa tersebut dengan asumsi belum tentu akan memperoleh harga atau fasilitas tambahan yang lebih baik sekalipun mendapatkan harga yang jauh lebih murah

\section{SIMPULAN DAN SARAN Simpulan}

Model regresi yang dihasilkan terbebas dari gejala-gejala asumsi klasik dan telah memenuhi uji normalitas, multikolinieritas, heteroskedastisitas. Nilai korelasi antara variabel bebas dan variabel terikat berada pada kategori kuat dan memiliki nilai koefisien determinasi sebesar 70,60 \% dimana kepuasan, kepercayaan dan harga mampu menjelaskan loyalitas wisatawan. Uji validitas dan reliabilitas terhadap instrument menyatakan keseluruhan indikator dalam kuisioner telah valid dan reliable sehingga layak dalam pengambilan data.

Uji hipotesis dengan menggunakan uji $t$ (parsial) menyatakan variabel bebas berpengaruh positif dan signifikan terhadap loyalitas wisatawan diketahui dari nilai $t$ hitung lebih besar dari nilai $t_{\text {tabel }}$ dan nilai signifikansi $<0,05$, sehingga hipotesis dapat diterima dengan indikator yang mendominasi dari masing - masing variabel adalah pengalaman, kebaikan hati, potongan harga dan pembelian secara berulang.

Sedangkan uji secara simultan dengan menggunakan uji F maka diketahui Kepuasan, kepercayaan dan Harga secara bersama sama mempengaruhi loyalitas wisatawan dalam menggunakan layanan Booking.com dengan nilai $F$ hitung $>F$ tabel. Hasil Uji $F$ menyatakan pula bahwa harga merupakan variabel paling dominan yang mempengaruhi loyalitas wisatawan untuk terus menggunakan layanan Booking.com.

\section{Saran}

Booking.com harus menyediakan pelayanan yang lebih atraktif bagi wisatawan, meningkatkan kepedulian dengan menanggapi permasalahan yang dihadapi wisatawan secara cepat (fast response), menyediakan fasilitas filter credit card untuk meningkatkan kenyamanan dan keamanan wisatawan dalam bertransaksi, meningkatkan kejelasan content website dan keseluruhan informasi sehingga informasi yang diperoleh wisatawan pada website sesuai dengan keadaan sebenarnya ketika wisatawan tiba di hotel. Variabel harga adalah yang mendominasi dalam mempengaruhi loyalitas wisatawan maka disarankan pula agar lebih berhati - hati dalam menetapkan harga pada website, karena harga sangat mempengaruhi sensitivitas wisatawan untuk terus melakukan pemesanan.

Dalam penyempurnaan penelitian ini maka diharapkan adanya penelitian lanjutan dengan menambah variabel bebas yang nantinya dapat memperjelas loyalitas wisatawan dan dengan menambah jumlah responden untuk penelitian selanjutnya.

\section{DAFTAR PUSTAKA}

Anonim. 2014. The 2014 Traveler's Road to Decision. Tersedia di www.thinkwithgoogle.com. Diakses 22 Desember 2015

Ernawati, N \& Nina Kurniasari. 2012. Pengaruh Kepuasan Pelanggan, Kepercayaan dan Harga terhadap Loyalitas Pelanggan Laundry Kencling Semarang.Jurnal Mahasiswa $Q$ MAN, Vol 1, No.3 , 57-68.

Griffin, Jill. 1995. Customer Loyalty, How to Earn It.How to Keep It .Loxington: Books an Imprint of The Free Press.

Herington, Carmel. 2003. Trust One Dimension or Two Market Orientation and Relationship Marketing. ANZMAC Conference Proceedings Adelaide Griffith University

Lombard, M.Roberts dkk. 2009. Customer Satisfaction, Trust and Commitment as 
Vol. 4 No. 2, 2016

Predictors of Customer Loyalty withinan Optometric Practice Environment. Southern African Business Review Volume 16 No 32012.

Putro. Kristian Haryono.2008. Analisis Pengaruh Kepercayaan Konsumen Terhadap Loyalitas Rokok Merk La Lights (Survei Pada Konsumen La Lights di Eks Karesidenan Surakarta. Tesis. Program Pasca Sarjanan Universitas Negeri Sebelas Maret Surakarta.

Sarwar, Muhammad Zaman. 2012. The Effect of Customer Trust on Customer Loyalty and Customer Retention: A Moderating Role of Cause Related Marketing.Global Journal of Management and Bussiness Research, Vol 12 (6).

Sujarweni, Wiratna. 2015. SPSS Untuk Penelitian. Yogyakarta : Pustaka Baru Press.

Virvilaite, Regina. 2009. The Relationship Between Price and Loyalty in Service Industry. Inzinirine Ekonomika Engginering Economics 3 (ISSN 13922785).

Wilkie, William L. 1994. Consumer Behaviour. New York: Third Edition Wiley \& Sons Inc.

Weenas, Jackson RS. 2013. Kualitas Produk, Harga, Promosi dan Kualitas Pelayanan Pengaruhnya Terhadap Keputusan Pembelian Spring Bed Comforta. Jurnal EMBA Vol.1 No.4. Hal 607 - 618. 